\title{
Tactical Criminal Investigations: Understanding the Dynamics to Obtain the Best Results without Compromising the Investigation
}

\author{
*Richard Reyes \\ Department of Law and Police Science, John Jay College of Criminal Justice, USA
}

Submission: February 03, 2017; Published: March 15, 2017

*Corresponding author: Richard Reyes, Department of Law and Police Science, John Jay College of Criminal Justice, 524 West 59th Street, New York, NY 10019, USA, Tel: 973-330-7619; Email: rreyes@jjay.cuny.edu

\begin{abstract}
The Rand Corporation study on criminal investigations [1] has been the classic research on criminal investigations that we refer to when reviewing and the efficacy of the detective in relations to policing. The research that has been conducted and reviewed providing a better understanding of the criminal investigations, case clearance and the detectives role has not been applied in most police departments and as a result very little has change in criminal investigations since the Rand Corporation study. This paper reviews the recent literature on criminal investigations in relations to the Rand Corporation study, and focuses on specific tactics of a criminal investigation to enhance the outcome and create higher clearance rates. Recognizing that U.S. crime statistics from the Uniform Crime Report (UCR) may not provide an accurate method to gauge crime and clearance rates tactical criminal investigations in conjunction with a properly managed case management system can produce more accurate data on investigative efficiency and lead to better work performance and accurate clearance rates.
\end{abstract}

Keywords: Police; Detectives; Criminal investigation; Tactics; Workload; Legitimacy

Abbreviations: UCR: Uniform Crime Report; AFIS: Automated Fingerprint Identification System; NIBIN: National Integrated Ballistics Identification Network

\section{Introduction}

Police departments throughout the United States are facing new challenges in policing specifically because of the financial restraints that have been placed on them. Many departments are finding themselves with the challenge of trying to reconcile the prospect of doing more with the reality of having less. As a result of the current times which place more on police efficacy, the priorities in policing will be decided by the funding provided to the police [2-4]. In turn leaves police departments having to resort to more efficient managerial practices to be able to protect and serve their communities at a time where the nation is confronted with new challenges caused by technology, the internet and social media; as well as old challenges caused by gang violence, gun violence, and the opioid epidemic, to mention a few. One of the area's most affected by these challenges, fall into the category of criminal investigations [5]. Although there has been a decreased in violent crime in the past twenty years, today, we are starting to see a rise in violent crime, cyber crime and property crime [6].
With fewer resources available police departments have to identify new innovative ways to conduct criminal investigations getting the best results without compromising the investigation. Tactical criminal investigation is a specific plan created to achieve a particular goal in the context of a criminal investigation. Webster defines tactics as, "the art or skill of employing available means to accomplish and end [7]." Police departments have to re-evaluate the role of the detective in respects to the needs and effectiveness of their position. Police departments that conduct investigations that are conducted tactically are more effective in reaching a conclusion than using previous strategies that are less effective. Tactics such as

i. Using a team approach rather than assigning the investigation to a single or pair of detectives;

ii. Early response to a crime scene, rather than the traditional follow-up investigation, which may not be assigned until the following day; 
iii. Immediate interview of the victim(s) and / or witness(s), to ensure the most accurate information and / or identification of the perpetrator(s).

The current research we have on clearance rates and detectives has brought into question the effect of criminal investigations in regards to general crime prevention and case closure. The classic RAND Criminal Investigation Study on detectives revealed that 30 percent of criminal offenses closed with an arrest were done due to the actions of the 1st officer at the scene. The study further found that 50 percent of criminal offenses closed with an arrest were the result of the victim and or witness knowing the suspect, like in domestic violence assaults or neighbor disputes, etc. The remaining 20 percent, the RAND study concluded, that only three percent of all index crime arrest were closed through the efforts of a criminal investigation crimes committed by unknown offenders [1]. Worrall [2] found that the use of crime rates can be an indicator of detective's workload but that they do not reflect how effective they are. To be able to measure the effectiveness of a detective or of criminal investigations you have to review the clearance rates. Ousey and Lee [8] in their research on homicide clearance rate reported a possible corroborated effect between clearance rates and the community. They found that throughout the country as homicide clearance rates have gone down, incarceration rates have gone up. They espouse this data as a possible factor that adds to the lack of police legitimacy within urban minority communities.

Braga and Dusseault [6] also concluded that community views of law enforcement legitimacy can also be affected by the clearance rates of crime in their community. Of all the functions related to policing, criminal investigations is the most coveted and revered in popular culture. Detectives have acquired an elite status, which provides them with higher pay and promotional opportunities along with flexibility and discretion in performing their assignment [6]. However, the ability of detectives to solve criminal investigations may not match the perception that has been romanticized in books, TV and the movies. Even though technology has improved the ability of identifying the perpetrators of crime, through the Automated Fingerprint Identification System (AFIS), National Integrated Ballistics Identification Network (NIBIN), DNA testing, facial recognition software, computer database, etc., Braga and Dusseault [6] found that clearance rates of homicides had not improved.

\section{Discussion}

How can police departments improve criminal investigations clearance rates and at the same time build legitimacy within their community? The use of the UCR for crime rates and case closure may not provide an accurate depiction of the efficiency and quality of the police response [9]. Understanding that due to the limited resources a police department has, not all crimes will be investigated, a more effective way to properly evaluate and therefore be more effective in the police department's investigative clearance rates, management should be evaluating case closure based on case assignments providing a more accurate of the detectives ability and productivity [10]. Crime rates have the ability to be subjective based on the methodology used to gather the information. Less than $50 \%$ of Part 1 crimes listed in the UCR are reported to the police, and of the crimes that have been reported to the police less than $50 \%$ are solved by the police [11]. Crime rates may further be skewed when taking into consideration offenders that tend to commit multiple crimes before being apprehended; and when apprehended are often just charged with the crime they were arrested for and not all the crimes they committed [12]. Detectives need to be trained and become proficient in the tactics necessary to conduct criminal investigations; such as, crime scene investigation, witness and camera canvass, interview and interrogation, computer data searches, laws of arrest, search and seizure, as well as case preparation and skilled at testifying, etc.

The use of proper tactics in criminal investigations is one way that police departments can increase their clearance rates with limited resources. Departments need to review their policies and procedures on how criminal investigations are assigned to determine if their greatest resource, the detective, and the detectives time, are being properly utilized to the greatest efficient results [4]. Police supervisors and managers need to create policy and procedures to ensure their detectives are approaching every investigation tactically and expediently without compromising the investigation. Supervisors can do this through a proper case management system that tracks the investigation from the beginning to the end, holding every detective and supervisor accountable for the results of the investigations [12]. Through a case management system a true picture will develop on the detective's workload and efficiency in solving criminal investigations. Too often a confirmation bias is present where we believe what we expect (perception) and not what has occurred (reality), [13]. Often this is a result of the halo effect; detectives speak openly and proudly about the cases they have closed, but rarely discuss the cases that have not been resolved [14].

Eck [15] found that detectives categorize criminal investigations into three separate categories which he calls the Implied Triage System. The categories include

i. cases that cannot be solved;

ii. cases that have already been solved; and

iii. Cases that can be solved.

Just as an emergency room doctor or nurse will triage a patient and prioritize the emergency, police administrators and supervisors need to follow that triage model in criminal investigations, placing them into priorities and recognizing that with the limited amount of time and resources effort should be placed on the cases with the highest probability of being resolved. 
Wellford and Cronin [16] found that homicide clearance rates can be improved with 3 factors:

i. dedication of adequate resources;

ii. training; and

iii. Better practices and procedures.

Understanding these threefactors is an appropriate beginning to understanding the process of a criminal investigation. As previously mentioned, one of the areas of concern in criminal investigations is the lack of resources, specifically the lack of manpower. Researchers have identified that police departments that assign four to five detectives to investigate homicides are found to have greater success in clearance rates than departments that assign one or two. Furthermore, if the detectives assigned to the criminal investigations have received proper training and are experienced their success rate improves [4]. Research has further identified that criminal investigations have a higher probability to be solved if the detectives have a prompt response to the crime scene, within 30 minutes, allowing the detectives to speak directly to the victim and or witnesses at the onset of the investigation [4]. This data is supported by the Rand Corporation study where 80 percent of offenses resulting in arrest are solved by the officers that responded to the crime scene [1]. The prompt appearance of detectives at the scene would enhance the investigation and lead to greater case clearance.

Training and education has also been found as another major factor to increase case clearance rates. Better training and education on criminal investigations, interview and interrogation, information technology, especially in this age of computers, cell phones, surveillance cameras, etc.; detectives have a wealth of resources at their fingertips. Through the use of computer database that include from criminal history, motor vehicle, department of correction, social media, real estate, etc. detectives have more information about an individual than ever before [4]. In the RAND study, they found that police departments with a higher percentage of crime per police officers, reported lower rates of arrest than departments that had a lower percentage of crime per police officers [1]. These results have been seen with police departments that serve more rural communities, which by the very nature of their policing environment have to resort to more community oriented policing practices. Police in rural areas continue to have a greater clearance rate than police departments in urban areas and greater community trust [8]. The benefits from a rise in criminal investigations clearance rates go beyond the obvious need for justice. In the era where there is a lack of trust between the community and the police, solving crimes can be a conduit to establishing trust [17].

Community policing and proactive policing includes detectives solving crimes, which result in the prevention of future crimes [18]. Often the police and community find themselves in a vicious cycle of mistrust that leads to a lack of cooperation with the police, which further adds to the failure to solve crimes. Police departments have to recognize that building a level legitimacy between the community and the police will reverse the cycle of mistrust, raise solvability, lower crime and benefit the communities they have sworn to protect [19]. Tactical criminal investigation is the ability to recognize evidence based policing strategies that enhance the ability for a detective to resolve their investigation. The tactics are clear and concise: team of detectives, early response to a crime scene, and division of investigative responsibility to gather as much information and evidence, before the information or evidence is lost. However, precautions have to be taken to ensure that for expediency sake the detectives do not resort to taking shortcuts that may be detrimental to the legal rights of all persons involved, to include the perpetrator. Constitutional rights and evidentiary procedures may never be compromised for the expediency to resolve an investigation.

\section{Conclusion}

With all the advances in police science, criminology and technology, we find that criminal investigations clearance rates have not changed in over 40 years. Police departments are hesitant or reluctant to change their methodology although there is evidence through research and practice indicates provides better criminal investigation practices to improve case clearance [6]. Daniel Kahneman [13] identified a confirmation bias in all of us; we believe what we expect will happen will happen. We believe that detectives will solve cases. Detectives have always been romanticized as elite, resourceful and extremely capable. On TV a detective can solve a homicide in less than an hour and come back the following week and do it again. Detectives remind each other of their successful investigations, often times through war stories, reinforcing the romanticized belief in their ability. To counter the confirmation bias or halo effect police administrators and supervisors must change their policies and procedures to create a case management system that allows them to review the data and get an accurate understanding of the outcomes of criminal investigation and the detective's performance. Through the proper gathering of data a more accurate evaluation can be done of the detectives, supervisors and the Division.

A true case management system set up with ticklers that are used by the supervisor to ensure that the detectives are using their time efficiently [14] and not procrastinating, will ensure the timely submissions of reports and indicate the outcome of the investigation [20]. Case management system should be divided into two parts, the role of the commanding officer / supervisor and the detectives function [10]. Commanding officer / supervisor role should include:
i. policies and procedures;
ii. ensure training is conducted; 
iii. case assignments by priority;

iv. the assignment of four to five detectives on investigations;

v. case review and recommendations; and

vi. Periodic evaluations.

The detectives' function, which should include:

i. Immediate response to crime scene;

ii. ensure all victim(s), witness(es), suspect(s) are properly interviewed;

iii. ensure crime scene has been documented and evidence properly collected and stored;

iv. canvass for witnesses and surveillance recordings;

v. review for patterns of crimes;

vi. review available database;

vii. ensure evidence is prepared and transported to the lab;

viii. make arrest if probable cause has been established;

ix. prepare investigative reports for supervisory review; and

x. Prepare all documents and evidence for trial.

Not much research in criminal investigations has been conducted since the landmark Rand Corporation study on criminal investigations. Criminal investigation is one area in policing that has not received sufficient attention from academics and practitioners to further advance the field. Further research should be conducted, specifically to identify policy and procedures that will assist the detective in successfully closing their investigations and perhaps being part in regaining a level of legitimacy in the community $[21,22]$.

\section{References}

1. Peter W Greenwood (1979) The Rand criminal investigation study: Its findings and impacts to date. Rand Corporation, USA.

2. John L Worrall (2016) Investigative resources and crime clearance: A group-based trajectory approach. Criminal Justice Policy Review: 1-16.
3. Worrall JL (2006) Crime control in America: An assessment of the evidence. Allyn and Bacon, USA.

4. Charles Wellford, James Cronin (2000) Clearing Up Homicide Clearance Rates. National Institute of Justice Journal: 1-7.

5. Foster RE (2005) Police Technology. Pearson, USA.

6. Anthony A Braga, Desiree Dusseault (2016) Can homicide detectives improve homicide clearance rates? Crime \& Delinquency: 1-33.

7. Definition of tactics. (n.d.) In Merriam-Webster.

8. Graham C Ousey, Matthew R Lee (2010) To know the unknown: The decline in homicide clearance rates, 1980-2000. Criminal Justice Review 35(2): 141-158.

9. Crime in the US 2015 (n.d.) (2015) In FBI UCR. USA.

10. Kilfeather RF (2011) Managing and coordinating major criminal investigations $\left(2^{\text {nd }}\right.$ edn). CRC Press, USA.

11. John Gramlich (2017) Most violent and property crimes in the U.S. go unsolved. In Pew Research Center, USA.

12. Kennedy DM (2011) Don't Shoot: One man, a street fellowship, and the end of violence in inner-city America. Bloomsbury, USA.

13. Kahneman D (2011) Thinking, Fast and Slow. Farrar, Strauss and Giroux, USA

14. Hess K, Orthmann CH, Ladue S (2016) Management and Supervision in Law Enforcement ( $7^{\text {th }}$ edn). Cenage Learning, USA.

15. Eck JE (1992) Criminal Investigation. In: G Gardner \& D Hale (Eds.) What works in policing? Operations and administration examined. Anderson, USA, p. 19-34.

16. Wellford C, Cronin J (1999) An analysis of variables affecting the clearance of homicide: A multistate study. Justice Research and Statistics Association, USA

17. Mike Maciag (2015) Case Closed? How 'solved' murder stats are misleading. In Governing, USA.

18. Mark Funkhouser (2016) Just Catch the Killers. In Governing, USA.

19. German Lopez (2017) The great majority of violent crime in America goes unsolved. Vox-Explain the News, USA

20. Ariely D (2008) Predictably Irrational. HarperCollins, USA.

21. Haidt J (2012) The Righteous Mind. Vintage Books, USA.

22. Holt TJ, Bossler AM, Seigfried-Spellar KC (2015) Cybercrime and Digital Forensics. Routledge, USA.
Your next submission with Juniper Publishers will reach you the below assets

- Quality Editorial service

- Swift Peer Review

- Reprints availability

- E-prints Service

- Manuscript Podcast for convenient understanding

- Global attainment for your research

- Manuscript accessibility in different formats (Pdf, E-pub, Full Text, Audio)

- Unceasing customer service

Track the below URL for one-step submission https://juniperpublishers.com/online-submission.php 